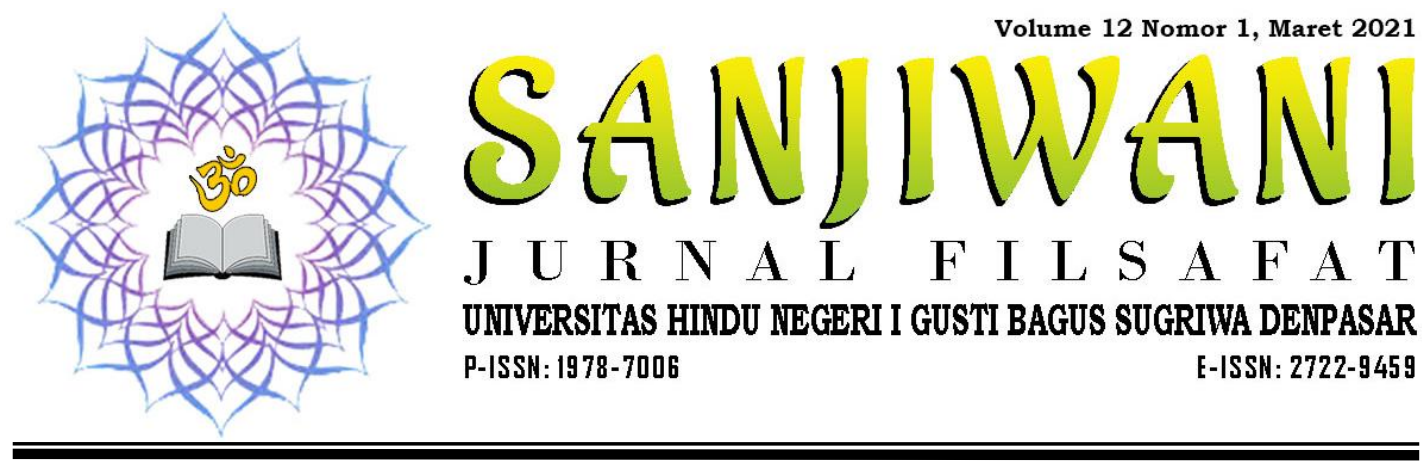

\title{
Hyper-Ritualitas : antara Determinisme Teknologi dan Hindu Nusantara
}

\section{Hari Harsananda ${ }^{1}$, Acyutananda Wayan Gaduh ${ }^{2}$}

Universitas Hindu Negeri I Gusti Bagus Sugriwa Denpasar ${ }^{1,2}$

dosenpolos@gmail.com ${ }^{1}$, acyutanandagaduh@gmail.com ${ }^{2}$

\begin{tabular}{|ll|}
\hline Keywords: & ABSTRACT \\
\hline Hyper-Rituality; & The world is entering the post-modern era with the Covid-19 \\
Technological & pandemic has further strengthened the existence of technology in \\
Determinism; & the world. Technological developments are increasingly advanced, \\
Hindu & penetrating other cultural elements, including the religious system. \\
& Technological determinism forms a "simulacra" that turns ritual \\
& into hyper-rituality. Rituals formed artificially through the \\
& internet network. Hindu Nusantara has a formulation in the form \\
& of Mantras, Mudra, Aksara, Mandala, Yantra and Kala which is a \\
& reason, that technological determinism that makes Hyperituality is \\
& actually a process of reducing the spiritual values of a religious \\
& ritual.
\end{tabular}

\begin{tabular}{|ll|}
\hline Kata Kunci & ABSTRAK \\
\hline Hyper- & \multicolumn{1}{c|}{ Dunia sedang memasuki era post-modern dan dengan } \\
Ritualitas; & adanya pandemi Covid-19 menjadikan teknologi \\
Determinisme & menguatkan eksistensinya di dunia. Pengembangan \\
Teknologi; & teknologi yang sangat maju kini juga mulai memasuki \\
Hindu & wilayah unsur kebudayaan yang lainnya termasuk sistem \\
& keyakinan atau sistem religi. Determinisme teknologi \\
& membentuk sebuah "Simulacra" yang mengubah ritual \\
& menjadi hyper-ritualitas. Ritual tersebut dibentuk secara \\
& artifisial di dalam jaringan internet. Hindu Nusantara yang \\
& memiliki formulasi yang terdiri dari Mantra, Mudra, Aksara, \\
& Mandala, Yantra dan Kala yang menjadikan determinisme \\
& teknologi dapat melahirkan hyper-ritualitas yang mampu \\
& mereduksi nilai - nilai spiritual dari sebuah ritual agama. \\
\hline
\end{tabular}

78 | SANJIWANI: Jurnal Filsafat Vol. 12 No. 1, Maret 2021 


\section{PENDAHULUAN}

Pandemi Covid -19 memberikan dampak yang luar biasa bagi kehidupan manusia, sejak konfirmasi kasus pertama di Provinsi Hubei, China pada November 2019 hingga diumumkan secara resmi pada Desember 2019, persebaran virus Covid -19 kian mengganas merambah berbagai Negara di Dunia. Presiden Joko Widodo sendiri pada akhirnya mengumumkan kasus Covid-19 pertama di Indonesia pada tanggal 2 Maret 2019, momen ini begitu penting dalam menghasilkan beragam kebijakan penangulangan pandemic Covid- 19 hingga sekarang.

Salah satu kebijakan yang popular tentunya pembatasan aktivitas umum bagi masyarakat. Program WFH (Work From Home), belajar dari rumah hingga pembatasan aktivitas ritual, dan aktivitas ekonomi. Menyiasati hal tersebut manusia dihadapkan pada pola kehidupan yang baru, memanfaatkan segala daya upaya, berusaha tetap normal meskipun dengan gaya yang berbeda (new normal). Kebudayaan baru tentu tercipta dengan kondisi yang demikian, kesenjangan budaya antara unsur Iptek dengan unsur kebudayaan lain yang memang ada sebagai perkembangan ide - ide manusia yang lebih modern, kini diperkuat implementasinya.

Cultural universal, sebuah konsep tentang tujuh unsur kebudayaan yang dinilai hadir membangun sebuah kebudayaan yaitu peralatan dan perlengkapan hidup manusia, mata pencaharian hidup dan system - sitem ekonomi, system kemasyarakatan, bahasa, kesenian, sistem pengetahuan dan religi atau sistem kepercayaan (Kluckhon dalam Soekanto, 2012). Unsur - unsur di atas, selain menjadi penopang, sesungguhnya memiliki keterkaitan satu dengan lainnya, jika dikaitkan dengan konsep fisika, maka antara satu - unsur dengan unsur lainnya sesungguhnya beresonansi, atau dalam bahasa yang lebih mudah, perubahan pada satu untur, akan mengakibatkan perubahan pada unsur lainnya. Hal inilah yang mengakibatkan terjadinya kesenjangan budaya atau culturall lag, sebuah kondisi salah satu unsur kesulitan mengejar perkembangan yang sangat cepat dari unsur yang lain.

Pada kasus pandemic covid-19 ini, hal seperti penjelasan di atas sungguh dan sangat terasa terjadi pada dimensi kehidupan manusia, pemanfaatan teknologi yang massif pada keenam unsur kebudayaan lainnya tidak hanya mengubah dimensi manifest dari unsur kebudayaan tersebut, namun perubahan laten dari dimensi nilai dan makna juga secara massif dapat dirasakan. Pembahasan pada artikel ini berusaha menguak perubahan - perubahan secara manifest dan laten tersebut serta mengkaji secara mendalam tentang implikasi dari pemanfaatan teknologi pada ruang ruang religi masyarakat terutama pada system ritual yang erat kaitannya dengan masyarakat Hindu di Indonesia secara umum dan masyarakat Hindu di Bali secara khususnya.

\section{PEMBAHASAN}

\subsection{Realitas Ritual, Teknologi dan Simulakra}

Teknologi memang salah satu aspek dalam hidup manusia yang kemajuannya dapat dikatakan paling cepat, sejak hingga pasca perang dunia kedua, pemanfaatan teknologi tiada habisnya hingga memunculkan revolusi 
industri seri 3 dan 4 . Teknologi di bidang informasi menjadi cabang yang paling terasa perkembangannya. Social media, e-commerce hingga aplikasi Meeting Online hadir merasuk pada sendi kehidupan masyarakat dengan pengguna lintas usia.

Bertepatan dengan pandemi Covid-19 yang melanda dunia, program kegiatan dengan prioritas tetap berada di rumah atau Work From Home menjadikan media meeting online beserta aplikasi berbasis video call semacam, WhatsApp, Telegram, Line dan lain sebagainya sebagai instrument utama dalam berkegiatan, webinar atau seminar berbasis daring, halal-bihalal, rapat dan beragam kegiatan yang pada awalnya merupakan sebuah pertemuan, kini pertemuan tersebut telah dilakukan secara daring (on-line).

Melihat realitas tersebut, tidak mengherankan bahwa penggunaan aplikasi meeting online terus mengalami peningkatan dari sisi kuantitas pengguna layanan tersebut seperti yang termuat dalam grafik yang bersumber dari Statqo Analytics sebagai berikut:

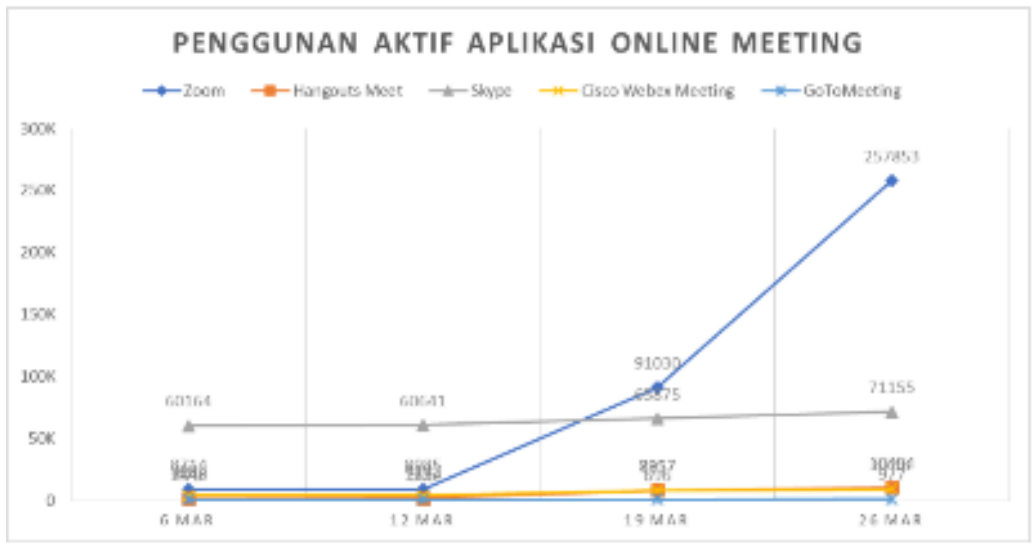

Gambar 1: Grafik Penggunaan Aplikasi On-line Meeting selama Pandemi Sumber : https://id.statqoanalytics.com/post/press-release-per-30-maret-2020edisi-ke-2-analisis-digital-terkait-dampak-pandemi-covid-19

Selain aplikasi meeting online, aplikasi perpesanan instan yang memiliki fitur panggilan Video juga tengah digandrungi serta menjadi instrumen alternatif bagi masyarakat yang ingin berkumpul dengan masyarakat lainnya namun terkendala akan protokol kesehatan. Realitas ini tentu tak dapat ditampik keberadaaanya, meningkatnya eksistensi cyber space sebagai "dunia kedua" kian merambah dimensi kehidupan lainnya tak terkecuali pada dimensi Sistem religi masyarakat. Menurut Durkheim dalam kebudayaan masyarakat, agama merupakan bagian paling berharga dari keseluruhan kehidupan sosial, agama melayani masyarakat dengan menyediakan ide, ritual dan perasaaan-perasaan yang akan menuntun seseorang dalam hidup bermasyarakat (Durkheim dalam Pals, 2012). Hal tersebut menjadikan agama berperan bagi masyarakat untuk tetap pada dimensi kolektifitas dari masyarakat tersebut, tidak mengherankan pada masa pandemi, situasi yang memutus konektifitas kolektif memerlukan agama dan ritual untuk mengembalikan sisi sosial dari individu meski alternative yang mulai terpikirkan di masa pandemic dengan protokol kesehatan

80 | SANJIWANI: Jurnal Filsafat Vol. 12 No. 1, Maret 2021 
yang ketat adalah aktivitas religi berupa ritual tersebut dilaksanakan secara OnLine.

Fenomena ini menurut Pilliang dapat termasuk ke dalam dimensi Post Realitas, sebuah realitas baru yang tercipta secara artifisial lewat bantuan ilmu pengetahuan, teknologi dan seni yang mutakhir (Pilliang, 2010). Realitas sosial baru ini berkembang bukan pada ruang sosial atau social space yang riil melainkan pada ruang sosial yang bersifat artifisial atau virtual ( virtual social space) yang di sediakan oleh dunia yang disebut Cyber - space atau ruang maya yang di dalamnya seseorang dapat mengubah peran, identitas dan konsep diri sesuai dengan keinginannya (Muhammad, 2014), dalam cyber-space, simulacra hadir menjadi instrument yang paling dominan yang berfungsi sebagai jembatan antara realitas sosial yang riil dengan realitas sosial yang artifisial, sebab simulacra sendiri merupakan seperangkat instrument yang mampu merubah hal - hal yang bersifat abstrak menjadi konkret dan begitu pula sebaliknya (Ritzer, 2012), di dalam kamus Oxford advance Learner's, istilah simulacra diartikan sebagai sesuatu yang tampak atau dibuat tampak seperti sesuatu yang lain (Pilliang, 2010).

Berdasarkan penjelasan di atas dapat dijelaskan bahwasanya, Simulakra yang hadir memberi efek tiruan (simulasi) dari realitas yang sesungguhnya, dan aplikasi meeting online serta perpesanan instan hadir sebagai bagian dari simulacra tersebut, baik video, foto, hingga video siaran langsung sesungguhnya merupakan sesuatu realitas yang abstrak, namun "seolah -olah" terasa menjadi suatu realitas yang kongkret. Pengaruh dari simulacra dalam tataran ritual nampaknya kian berdampak belakangan ini, dengan realitas yang terkesan konkretnya, banyak ritual keagamaan yang kini dihadirkan secara On-Line seperti salah satu foto di bawah yang diperoleh dari salah satu grup Facebook " HINDU".

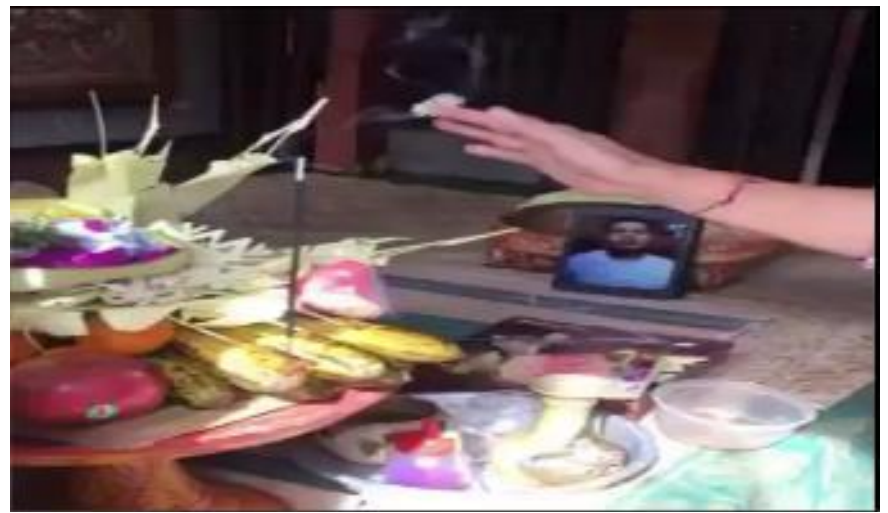

Gambar 2 : Prosesi Otonan via aplikasi meeting On-Line Sumber :

(www.facebook.com/groups/247569498772568/permalink/1099021380294038)

Tampak pada gambar di atas, foto dari seseorang yang tengah melalui proses ritual secara On-Line dengan menggunakan fitur panggilan video, pada kesempatan inilah gawai beserta aplikasi panggilan video menjadi simulacra atau instrument yang merubah sesuatu yang abstrak seolah - olah menjadi sesuatu yang kongkrit. Pada realitasnya, sesungguhnya sosok lelaki dalam video

81 | SANJIWANI: Jurnal Filsafat Vol. 12 No. 1, Maret 2021 
tersebut tidak hadir dalam dimensi ruang tersebut, namun dipaksa dihadirkan meski sifat kehadirannya semu. Fenomena seperti inilah yang menurut Pilliang disebut sebagai Hyper-ritualitas yaitu realitas ritual yang tidak lagi mengacu pada realitas di dunia nyata atau prisnsip asali yang membangunnya sebagai refrensinya, sehingga ia menjadi semacam realitas kedua, yang refrensinya adalah dirinya sendiri (Pilliang, 2010).

Aspek - aspek yang terlibat dalam ritual seakan - akan tampil seperti realitas yang sesungguhnya, atau hakiki, padahal ia adalah realitas artifisial, yaitu realitas yang diciptrakan sedemikian rupa sehingga pada tingkat tertentu ia tampak dan dipercaya sebagai bagian dari hakikat ritual kegamaan itu sendiri, hal ini sangat tercermin dari gambar di atas yang melalui panggilan video, orang yang melalui ritual seolah-olah hadir dan mengikuti ritual tersebut, padahal dalam realitas aslinya tidak mengikuti.

Hal tersebut tentu saja menempatkan teknologi berhadapan langsung dengan nilai -nilai kebudayaan yang telah ada sebelumnya, hal semacam ini sesungguhnya bisa dijelaskan melalui teori Determinisme Teknologi. Determinisme Teknologi pertama kali dikemukakan oleh Marshall McLuhan di tahun 1962 melalui tulisannya yang berjudul The Guttenberg Galaxy: The MakingTyphographic Man dengan pokok bahasan bahwa kehidupan masyarakat manusia, khususnya aspek interaksi sosial diantara mereka, ditentukan oleh perkembangan dan jenis teknologi yang dikonsumsi oleh masyarakat itu sendiri (Febriana, 2018), dalam rumusannya, Daniel Chandler mengemukakan beberapa asusmsi dasar dari determinisme teknologi yaitu :

1. Reductionistic : Determinisme teknologi menjadi sekat yang memberi jarak antara teknologi dan budaya, sehingga keberadaan teknologi sedikit demi sedikit menghilangkan beberapa nilai budaya yang selama ini ada di tengah - tegah masyarakat

2. Monistic : Determinisme teknologi menjadi factor penyederhana dari sebuah system yang rumit menjadi tampak lebih mudah.

3. Neutralizing : Pada dasarnya sifat teknologi adalah netral (tidak berpihak), baik -buruknya teknologi bergantung pada pemakainya.

4. Technological Imperatif: Sifat dasar teknologi yaitu pengembangannya tidak akan pernah dibendung serta selalu mengikuti perkembangan jaman dan budaya (Thurlow et al., 2004).

Jika di dasarkan pada teori Determinisme Teknologi di atas, maka sangat relevan jika ruang ritual keberagamaan juga mulai mengikuti perkembangan teknologi, namun sifat agama yang konservatif berkontradiksi dengan determinisme teknologi tersebut. Mereka yang menentang determinisme teknologi secara teoritis dapat dikategorikan sebagai kaum Social Construction atau kaum yang menjaga konstruksi sosial (Ratmanto, 2005), mengingat agama adalah sebuah lembaga normative, maka sesungguhnya produk determinisme teknologi seperti simulacra, cyber space serta aktifitas artifial memang memiliki sisi yang kontradiktif.

82 | SANJIWANI: Jurnal Filsafat Vol. 12 No. 1, Maret 2021 


\subsection{Hyper- Ritualitas menurut Hindu Nusantara}

Pada sub-bab sebelumnya telah dijelaskan konsep tentang hyper-ritualitas yaitu aktifitas ritual yang dibuat secara artifisial dengan simulacra sehingga aktifitas yang semu tersebut tampak nyata. Pada bagian berikut ini akan dijelaskan tentang hyper-ritualitas jika dikaitkan pada kaidah - kaidah Ritual Hindu Nusantara.

Wacana tentang Hindu Nusantara sesungguhnya bukan wacana baru, tidak hanya pada agama Hindu, banyak agama yang kini berusaha mencari "kemasan" yang bersifat local dengan "ide" yang tetap bersifat global. Secara tekstual, Hindu Nusantara merupakan Hindu yang secara ide berakulturasi dengan kebudayaan masyarakat DI Indonesia yang berpola kebudayaan agraris, hal tersebut menjadikan implementasi ajaran agama Hindu dalam dimensi Ritual erat kaitannya dengan Animisme dan Dinamisme, di tengah dunia yang mengangungkan Monotheisme, keyakinan akan animisme mungkin terkesan primitive dan terbelakang, namun jika melihat Hindu sebagai agama tertua, maka hal ini dapat dikatakan wajar. Tylor mengungkapkan bahwa Animisme yang berasal dari bahasa latin "Anima" yang berarti Roh merupakan keyakinan yang percaya terhadap sesuatu yang hidup dan punya kekuatan yang ada di balik sesuatu, serta Animisme adalah bentuk pemikiran paling tua yang dapat ditemukan dalam setiap sejarah umat manusia (Pals, 2012). hal ini menjelaskan bahwa sesugguhnya terdapat kekeliruan terhadap Animisme itu sendiri, karena selama sebuah agama masih meyakini tentang konsep "roh" baik secara imanen maupun transenden, ide ide animisme tetap melekat padanya.

Hindu Nusantara yang memiliki jiwa dasar Animisme, sesungguhnya memiliki suatu format yang baku, yaitu Panca Sraddha atau lima keyakinan utama yakni, Brahman ( yakin pada Tuhan Transenden), Atman (yakin terhadap Tuhan Imanen), Karma Phala ( yakin terhadap perbuatan dan hasilnya), Punarbhawa (yakin akan kelahiran berulang) serta Moksa ( yakin akan pembebasan abadi). Ke lima keyakinan ini di topang oleh Tri Kerangka Agama Hindu yaitu Tattwa (ide-ide kefilsafatan) Susila ( norma dan tata laku ) serta Acara ( segala yang berkenaan dengan ritus keagamaan). Secara konsep ide - ide tentang Animisme ini kerapkali terejawantahkan pada dimensi Acara yang ikut membangun dimensi Tattwa bagi Hindu Nusantara.

Tattwa yang berkembang di Nusantara merupakan Tattwa yang bermazhabkan paksa Siva Siddhanta, terdapat beberapa variable pembangun ajaran Siva Siddhanta ini, yaitu adanya, Mantra (doa suci), Mudra (gerak tangan), Aksara (huruf sakral), Yantra (sarana ritual), Kala (waktu), Mandala (tempat atau ruang) (Suamba, 2009). Relasi kontradiktif antara dimensi Hyper ritualitas dengan ajaran Siva Siddhanta sesungguhnya berda pada dimensi Kala, Mandala dan Yantra. Dimensi Kala membicarakan mengenai waktu dari pelaksanaan ritual tersebut, terdapat konsep ala-ayuning dewasa atau baik - buruknya hari untuk melaksanakan sebuah ritual keagamaan. Hyper - ritualitas memungkinkan seseorang berada dalam "kesempatan" yang sama namun pada "waktu" yang berbeda, hal ini disebabkan oleh waktu yang dibagi berdasarkan pada garis bujur dunia, sehingga antar satu wilayah dengan wilayah lainnya bisa memiliki selisih waktu yang berbeda, pada sistem "kala" hal ini tentu bermasalah karena

83 | SANJIWANI: Jurnal Filsafat Vol. 12 No. 1, Maret 2021 
menyebabkan setiap pelaku dari ritual tidak berada dalam dewasa ayu yang sama karena perbedaan waktu tersebut, contoh : dewasa ayu dalam melaksanakan sebuah ritual adalah hari rabu saat tengah hari, orang lain yang mengikuti ritual online belum tentu berada pada waktu dan hari yang sama, ini yang mengakibatkan terjadi distorsi pada ritual tersebut.

Variable yang kontradiktif kedua adalah variable Mandala atau ruang. Mircea Eliade dalam bukunya "The Sacred and The Profane" tahun 1957 mengungkapkan bahwasanya pada realitas agama selalu dibangun pada dua realitas yaitu Yang Sakral dan yang profan (Mircea Eliade dalam Pals, 2012). Yang Sakral merupakan realitas yang mengandung ide - ide ke-Ilahian sedangkan yang profan merupakan realitas yang erat dengan aktifitas manusia biasa. Pada implementasinya, "Yang Sakral" dan "yang profan" selalu ada bahkan pada dimensi materi, hal ini disebabkan bahwa Ke-Ilahiahan dapat terkoneksi secara langsung melalui materi sebagai jembatan bagi "yang profan" untuk terkoneksi dengan "Yang Sakral" tersebut. Lebih lanjut Eliade mengemukakan konsep tentang Hierophany (berasal dari bahasa yunani, yaitu "hieros" dan "phaineien" yang berarti "penampakan Yang Sakral") secara konsep Hierophany ini adalah tempat - tempat yang diyakini sempat " dikunjungi" oleh Yang Sakral, bisa dalam bentuk Dewa atau arwah nenek moyang, tempat ini diyakini memperoleh karunia ilahi sehingga layak menjadi Axix Mundi atau pusat dunia (cosmos).

Pendapat Eliade sangat relevan dengan konsep mandala dalam ajaran Siva Siddhanta. Mandala sesungguhnya dapat terbagi menjadi Mandala Yang Sakral dan Mandala yang profan, hal ini dapat ditunjukkan dengan keberadaan tempat suci seperti Pura, Sanggah, Merajan, Kamar Suci, Palinggih. Tempat - tempat tersebut sebagai tempat yang sakral memiliki "kualitas" yang berbeda dengan tempat - tempat pada umumnya yang tidak dibangun dengan cara- cara yang sakral. Tempat - tempat suci ini juga diyakini menjadi pusat dari sebuah mandala atau ruang, contoh Sanggah atau Pamerajan adalah axix mundi dari sebuah rumah, kemudian Pura Kahyangan Tiga adalah Axix Mundi dari sebuah Desa Pakraman.

Dimensi Mandala memiliki sisi kontradiktif dengan ritus artifisial disebabkan karena tidak ada jaminan bahwa seluruh pelaku ritual berada pada dimensi Mandala Yang Sakral, kegiatan ritus artifisial memberikan perbedaan pada dimensi "ruang dan waktu", seperti foto yang dilampirkan di bawah ini:

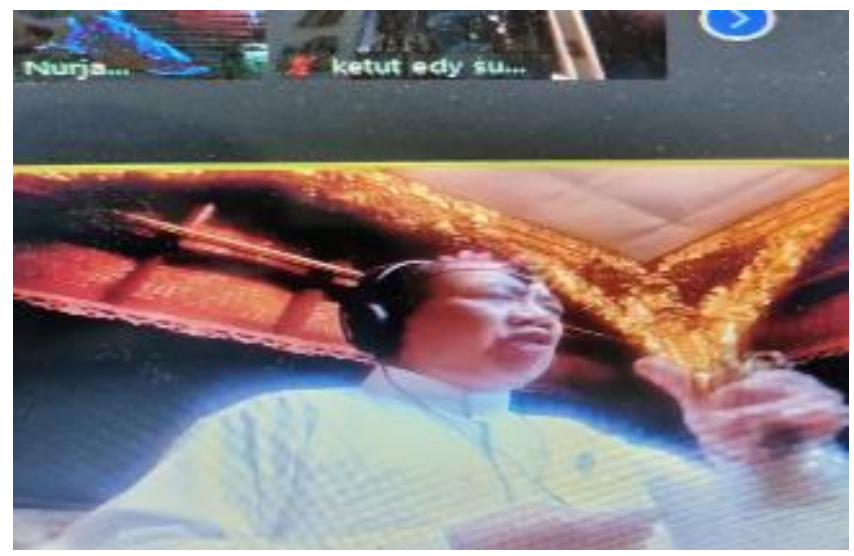

84 | SANJIWANI: Jurnal Filsafat Vol. 12 No. 1, Maret 2021 


\section{Gambar 3}

Ritus Mejaya-Jaya secara Online menggunakan aplikasi Zoom pengurus Ikatan Dosen Hindu Indonesia, tanggal 10 Januari 2021

(Sumber : Dokumen Pribadi,)

Hal yang mungkin terjadi adalah ketika sebuah ritus Yang Sakral dilaksanakan, pemuka agama dapat berada pada tempat yang representative untuk melakukan ritual, namun pesertanya tidak berada pada tempat yang baik untuk mendukung ritual yang tengah Ia jalani. Seperti foto di atas menunjukkan bahwa ada sebuah ritus (Mejaya-jaya) yang diselenggarakan secara online, tampak pemuka agama berada pada tempat yang representatif untuk memimpin dan menjalankan proses ritual, namun tidak ada jaminan yang sama bagi peserta lainnya. Situasi semacam ini koheren dengan asumsi tentang Determinisme Teknologi menurut Chandler yaitu Reductionistic yaitu keberadaan teknologi sedikit demi sedikit menghilangkan beberapa nilai budaya yang selama ini ada di tengah - tegah masyarakat (Daniel Chandler dalamThurlow et al., 2004). Reduksi dari nilai - nilai ritual inilah yang pada akahirnya menempatkan Mandala memiliki sisi kontradiktif dengan acara ritual artificial semacam itu.

Variabel ketiga dari Siva Siddhanta yang berkontradiktif dengan ritual artifisial adalah Yantra. Menurut P.H Pott Yantra is "aid" or "tool" specially employed as the name of aids which are used by yogis as aids to meditation, and which can also in many case used as receptacles for the Istadewata (alat atau media khusus yang digunakan sebagai sarana yang digunakan oleh para Yogi untuk melakukan meditasi dan juga pada banyak kesempatan digunakan sebagai sarana memuja Ista Dewata) (Suamba, 2009) didasarkan pada penjelasan dari P.H Pott, maka banten dan sararana upakara dalam sebuah ritual Hindu Nusantara dapat terkategori sebagai Yantra. Penggunaan yantra ini sesungguhnya berkaitan dengan keyakinan animisme pada pembahasan sebelumnya, pada Animisme dikenal dimensi spiritual bernama Magi. Secara garis besar dapat dikatakan bahwa magi adalah kepercayaan dan praktik menurut mana manusia yakin bahwa secara langsung mereka dapat mempengaruhi kekuatan alam dan antar mereka sendiri (Dhavamony, 1995). Maksud dari penjelasan tersebut adalah, Magi merupakan sebuah keyakinan tentang manusia yang diyakini memiliki kekuatan untuk mengatur kekuatan (energi) alam semesta. Magi diimplementasikan dalam Yantra berupa simbol - simbol yang diyakini simbol tersebut merepresentasikan kekuatan dari sesuatu yang disimbolkan tersebut. Salah satu contoh yang bisa digunakan adalah Tumpeng sebagai simbol gunung, maka kekuataan atau konsep gunung akan diyakini hadir setiap kali simbol tumpeng ini dipergunakan.

Yantra sebagai implementasi konsep Magi tak bisa dilepaskan begitu saja, hal ini tampak dari beragam ritual yang menggunakan yantra karena yantra tersebut diyakini mengandung kekuatan yang dapat di transformasikan secara langsung kepada manusia. Magi sendiri dapat terbagi menjadi du jenis yaitu Magi tiruan dan Magi sentuhan. Magi tiruan didasarkan pada prinsip kesamaan dalam bentuk, atau dalam proses; keserupaan menghasilkan keserupaan, (Dhavamony, 1995) maksudnya, Magi ini didasarkan pada pola tiruan akan

85 | SANJIWANI: Jurnal Filsafat Vol. 12 No. 1, Maret 2021 
suatu benda yang merepresentasikan benda lainnya, seperti nampak pada foto di bawah ini :

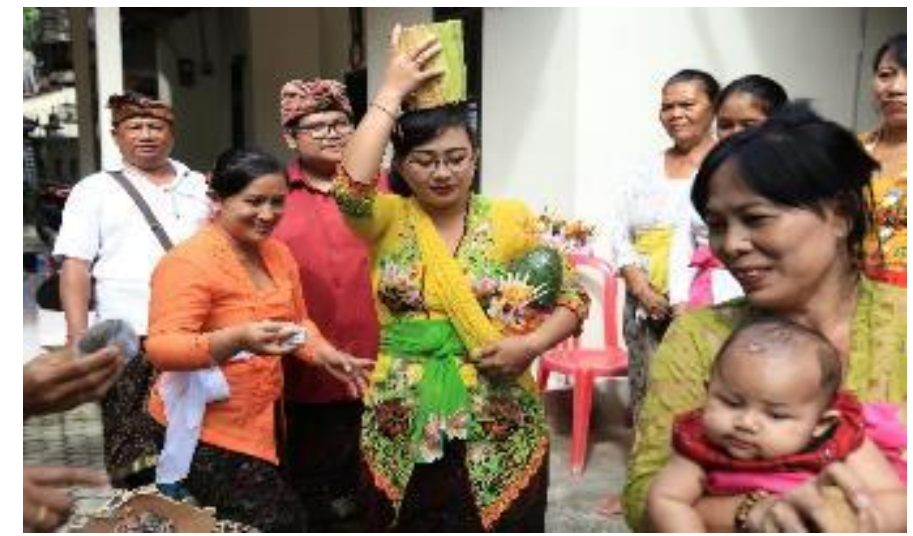

Gambar 4 : Salah satu prosesi dalam ritual 3 Bulanan Sumber : Dokumentasi Pribadi

Foto di atas adalah salah satu aktifitas ritual tiga bulanan, tampak sang ibu membawa buah Bligo yang merepresentasikan bayi yang kemudian buah Bligo itu akan ditukarkan kembali dengan bayi asli sebagai simbol penerimaan bayi secara utuh, inilah contoh penerapan magi tiruan pada sebuah Yantra. Jenis magi yang kedua adalah Magi sentuhan yang didasarkan pada hukum sentuhan fisik atau penularan dan pengaruh magis mempunyai dasarnya pada kontak fisik, contohnya ada pada gambar berikut :

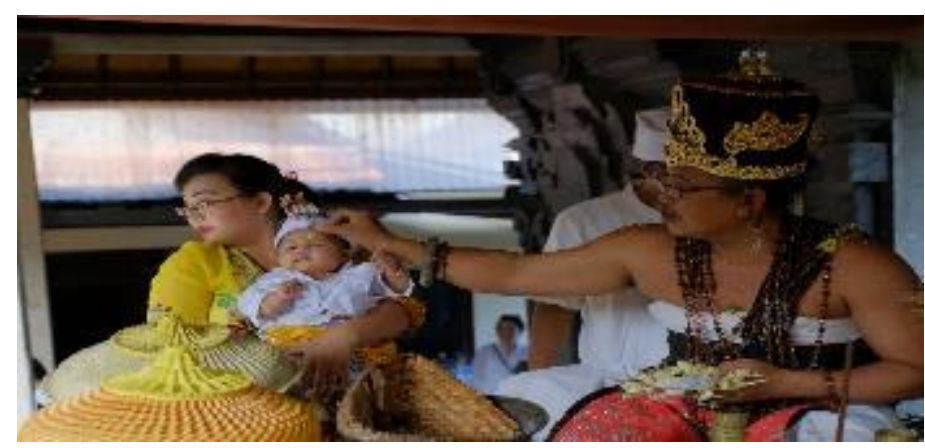

Gambar 5 : prosesi mèmèras saat upacara 3 bulanan Sumber : Dokumentasi Pribadi

Eliade merumuskan wujud lain dari Hierophany yaitu Theophany, konsepnya sama dengan Hierophany hanya perbedaan ada pada bentuknya. Theopany memiliki konsep manusia Ilahiah, jika pada Hierophany, Yang Sakral menghampiri suatu tempat, maka Theopany adalah manusia yang dihampiri oleh Yang Sakral, sehingga terwujudlah manusia yang menjadi Simbol dari Tuhan tersebut. Magi sentuhan sangat berperan pada dimensi ini. Sulinggih selaku Theophany melalui Magi sentuhan diyakini mampu meneruskan aspek Yang Sakral menuju bayi yang profan, sehingga sifat - sifat Keilahian mampu membumi. Pada dimensi inilah, ritual artifisial menemukan kontradiktifnya dengan aspek Yantra disebabkan dalam yantra, magi sentuhan dan magi tiruan sangatlah kental. Ritual artifisial yang dilakukan melalui media meeting online 
tidak akan menemukan sisi magi tersebut, yang menjadikan nilai Sakral dan religius dari sebuah ritus menjadi hilang.

\section{PENUTUP}

Manusia dihadapkan pada perkembangan teknologi yang kian massif, kondisi pandemic covid-19 seakan memperkuat hal tersebut. Determinisme teknologi ditambah simulacra menjadikan hyper ritualitas tak terbendung lagi, sayangnya pada agama Hindu Nusantara, konsep akan Mandala, Yantra dan Kala masih menjadi sebuah alasan, penguat bahwa hyper ritualitas sesungguhnya adalah sebuah gaya baru dalam beritual agama yang sejatinya mereduksi nilai nilai agama dan nilai spiritual dari sebuah ritual.

\section{DAFTAR PUSTAKA}

Azwar Muhammad. (2014). Teori Simulakrum Jean Baudrillard dan Upaya Pustakawan Mengidentifikasi Informasi Realitas. Khizanah Al-Hikmah, 2, 3848.

Dhavamony, M. (1995). Fenomenologi Agama. Kanisius.

Febriana, A. I. D. (2018). Determinasi Teknologi Komunikasi Dan Tutupnya Media Sosial Path. LONTAR: Jurnal Ilmu Komunikasi, 6(2), 86. https:// doi.org/10.30656/lontar.v6i2.948

Pals, D. L. (2012). Seven Theories Of Religion (2nd ed.). IRCiSoD.

Pilliang, Y. A. (2010). Post - Realitas, Realitas Kebudayaan dalam era Post Metafisika ( alfatri Adlin (ed.); 3rd ed.). Jalasutra.

Ratmanto, T. (2005). Determinisme_Teknologi_dalam_Teknologi_Komunikasi_. Mediator, 6, 43-49. https:/ / ejournal.unisba.ac.id/index.php/mediator/article/view/1175

Ritzer, G. (2012). Teori Sosiologi dari Sosiologi Klasik Sampai Perkembangan Terakhir Post Modern (8th ed.). Pustaka Pelajar.

Soekanto, S. (2012). Sosiologi Suatu Pengantar (44th ed.). PT. Raja Grafindo Persada.

Suamba, I. B. P. (2009). Siwa-Buddha di Indonesia: Ajaran dan Perkembangannya (2nd ed.). PT. Mabhakti.

Thurlow, C., Lengel, L., \& Tomic, A. (2004). Computer mediated communication: social interaction and the Internet. In Choice Reviews Online (1st ed., Vol. 42, Issue 02). Sage Publication Ltd. https:/ / doi.org/10.5860/choice.42-0992 